\title{
The Application of the Essential Oils of Thymus vulgaris L. and Crithmum maritimum L. as Biocidal on Two Tholu Bommalu Indian Leather Puppets
}

\author{
Giulia D’Agostino, Belinda Giambra, Franco Palla, Maurizio Bruno * $\mathbb{D}$ and Natale Badalamenti $(\mathbb{D}$
}

check for updates

Citation: D'Agostino, G.; Giambra, B.; Palla, F.; Bruno, M.; Badalamenti, N. The Application of the Essential Oils of Thymus vulgaris L. and Crithmum maritimum L. as Biocidal on Two Tholu Bommalu Indian Leather Puppets. Plants 2021, 10, 1508. https://doi.org/10.3390/ plants10081508

Academic Editor: Milan S. Stankovic

Received: 6 July 2021

Accepted: 19 July 2021

Published: 22 July 2021

Publisher's Note: MDPI stays neutral with regard to jurisdictional claims in published maps and institutional affiliations.

Copyright: (c) 2021 by the authors. Licensee MDPI, Basel, Switzerland. This article is an open access article distributed under the terms and conditions of the Creative Commons Attribution (CC BY) license (https:/ / creativecommons.org/licenses/by/ $4.0 /)$.
Department of Biological, Chemical and Pharmaceutical Sciences and Technologies (STEBICEF), Università degli Studi di Palermo, Viale delle Scienze, Ed. 17, I-90128 Palermo, Italy; giuliadagostino@outlook.com (G.D.); info@belindagiambra.it (B.G.); franco.palla@unipa.it (F.P.); natale.badalamenti@unipa.it (N.B.)

* Correspondence: maurizio.bruno@unipa.it; Tel.: +39-091-23-897-531

Abstract: The chemical profile of the Thymus vulgaris (Lamiaceae) essential oil (EO) was investigated in order to evaluate its biological properties against microorganisms affecting two Tholu Bommalu, typical Indian leather puppets stored at the International Puppets Museum "Antonio Pasqualino" of Palermo, Italy. A GC-MS analysis, using both polar and apolar columns, was used to determine the chemical composition of the essential oil. The aim of this study was to evaluate the antimicrobial effectiveness of the Thymus vulgaris and Crithmum maritimum essential oils in vapor phase to disinfect heritage leather puppets. Pieces of leather artifacts that were affected by different bacterial colonies were exposed to EO under vacuum and static evaporation conditions. The results presented showed that the vaporization of essential oil was an efficient method in the disinfection of natural skins, eradicating microorganism in short times. T. vulgaris EO in the $50 \%$ solution showed excellent inhibitory activity against isolated bacteria with both methods, but the obtained results suggest that the vacuum method allowed for faster exposition of the artifacts to the biocide. Furthermore, the biocidal properties of the essential oil of a Sicilian accession of Crithmum maritimum (Apiaceae) aerial parts were compared and investigated. The results of the latter essential oil showed a poor activity against the isolated micro-organisms.

Keywords: Thymus vulgaris; Crithmum maritimum; leather artifacts; essential oils; anti-bacterial activity

\section{Introduction}

Biodeterioration of cultural heritage causes different alteration processes affecting the constitutive materials of artworks. In particular, fungi and bacteria are able to colonize different artworks comprised of natural materials through aerosol pollution, representing complex problems for conservation by causing a loss of mechanic resistance and deterioration of pictorial layers. Moreover, inadequate exposure to specific thermo-hygrometric parameters can increase the concentrations of microbial colonies, enhancing the deterioration process. For the purpose of inhibiting the biological colonization, different chemical biocides, such as permethrin or/and benzalkonium chloride (BAK), are frequently used. These products are usually toxic for humans and the environment. Hence, in the last decade, essential oils have been applied in order to combat cultural heritage biodeterioration as an eco-friendly solution [1-12]. To prevent biodeterioration caused by fungi and bacteria, objects must first be disinfected. The requirements for a disinfectant include the ability to inhibit the growth and metabolic activity of microorganisms without adversely affecting the material. Currently, fumigation with ethylene oxide is the most popular method for disinfecting fabrics, papers and leathers. However, this gas is an irritant and a dangerous human carcinogen, and its use should be avoided [13].

However, the disinfection process by using volatile compounds, such essential oils (EOs), can require a long time, so the purpose of this work was to find a way to accelerate 
this. During the evaporation process of a specific liquid, the number of molecules escaping from the liquid increases every second and those that condense back into the liquid also increase. Reaching thermodynamic equilibrium, the vapor phase exerts a pressure on its condensed phase, which is called "vapor pressure" [14]. The speed with which the evaporation occurs is proportional to the vapor pressure of the liquid. The purpose of a vacuum pump applied to a closed system is to maintain a lower pressure than that of the atmosphere. In order to make our disinfection process faster, a vacuum pump was connected to a closed system, ensuring a higher evaporation of the EO contained inside.

To investigate a suitable alternative to traditional synthetic biocides, we decided to analyze the biocidal properties of two different essential oils: Thymus vulgaris L. (Lamiaceae) and Crithmum maritimum L. (Apiaceae).

Thymus EO was selected due to its microbial properties, which have previously been reported in several studies [15-21]. In particular, the Thymus vulgaris essential oil has been shown to be quite effective against several microorganisms [22,23].

In addition, the essential oil of Crithmum maritimum has been largely investigated [24]. Its antimicrobial properties have been studied [25,26], showing its antioxidant, antiinflammatory, vermifuge and antifungal potentials. In particular, the essential oil's capacity to inhibit two important virulence factors in Candida albicans, Cryptococcus neoformans and several dermatophytes and Aspergillus spp has been demonstrated.

There are no reports on the use of Thymus essential oil for leather disinfection to date. Thus, the main purpose of this study was to undertake the first study of the application of the Thymus essential oil to heritage leather disinfection under a vacuum system. Consequently, in the context of our ongoing research on endemic Sicilian plants [27-29] and the biological activity of essential oils [30-32], and in consideration of the important antibacterial properties of the essential oil Thymus demonstrated in the aforementioned articles, we decided to utilize the EO of Thymus vulgaris as natural biocide against bacteria affecting two Tholu Bommalu, typical Indian leather puppets, which were stored at the International Puppets Museum "Antonio Pasqualino". We exploited the high vacuum inside ad hoc chambers in order to speed up the disinfection process. The activity of the essential oil of T. vulgaris was then compared with that of Sicilian Crithmum maritimum EO. These results were compared with the results of using a conventional synthetic biocide, benzalkonium chloride, as a disinfectant.

\section{Results and Discussion}

\subsection{Gas Chromatography and Mass Spectrometry (GC-MS) Analysis of the Essential Oil}

The chemical composition of the essential oil of Thymus vulgaris was analyzed by GC-MS analysis and is reported in Table 1. Sixteen compounds, divided into three classes, were identified, accounting for $97.97 \%$ of the total composition. In terms of compound classes, monoterpene hydrocarbons (49.96\%) dominate the EO, with $p$-cymene as the most abundant compound (35.96\%), followed by terpinen-4-ol (10.29\%) and $\alpha$-terpinene $(8.85 \%)$. Oxygenated monoterpenes are also dominant $(43.67 \%)$ with thymol $(25.38 \%)$. In contrast, sesquiterpene hydrocarbons accounted for only $4.34 \%$; no oxygenated sesquiterpenes were identified in the chromatogram of the EO. Comparing different samples of T. vulgaris from Saudi Arabia [22] and France and Serbia [33] to our results, we found them to also be rich in not only thymol, $p$-cymene and $\alpha$-terpineol but also in camphene and caryophyllene.

The chemical composition of the essential oil obtained from Crithmum maritimum was analyzed by GC-MS analysis and is reported in Table 2. Forty compounds, divided into four classes, were identified, accounting for $90.03 \%$ of the total oil. In terms of compound classes, monoterpene hydrocarbons $(45.08 \%$ ) dominate the $\mathrm{EO}$, with $\beta$-myrcene as the most abundant compound (13.66\%), followed by $p$-cymene (11.67\%) and $\beta$-phellandrene (6.57\%). Oxygenated monoterpenes are also dominant $(40.03 \%)$ with thymol acetate $(14.38 \%)$. In contrast, hydrocarbon and oxygenated sesquiterpenes accounted for only $1.94 \%$ and $0.50 \%$, respectively. 
Table 1. Chemical composition of T. vulgaris essential oil.

\begin{tabular}{|c|c|c|c|c|c|c|}
\hline No. & Compounds & LRI $^{a}$ & LRI $^{b}$ & Area $(\%)$ & Ident. $^{c}$ & Ref. \\
\hline 1 & $\beta$-Pinene & 974 & 1070 & 0.08 & $1,2,3$ & \\
\hline 2 & cis-Carane & 978 & 1033 & 0.90 & 1,2 & \\
\hline 3 & $\beta$-Myrcene & 990 & 1079 & 2.54 & $1,2,3$ & \\
\hline 4 & 3-Carene & 1011 & 1129 & 0.48 & 1,2 & \\
\hline 5 & $\alpha$-Terpinene & 1018 & 1140 & 8.85 & $1,2,3$ & \\
\hline 6 & p-Cymene & 1021 & 1224 & 35.96 & $1,2,3$ & \\
\hline 7 & $\begin{array}{l}\text { (3E)-3-Ethyl-2,5-dimethyl-1,3- } \\
\text { hexadiene }^{\mathrm{d}}\end{array}$ & 1031 & 976 & 0.04 & 1,2 & \\
\hline 8 & Eucalyptol & 1035 & 1211 & 1.56 & $1,2,3$ & \\
\hline 9 & Terpinolene & 1084 & 1264 & 1.11 & 1,2 & \\
\hline 10 & $\beta$-Linalool & 1098 & 1498 & 5.99 & $1,2,3$ & \\
\hline 11 & trans-Pinocarveol & 1139 & 1666 & 0.45 & 1,2 & \\
\hline 12 & Terpinen-4-ol & 1177 & 1612 & 10.29 & 1,2 & \\
\hline 13 & Thymol & 1267 & 2156 & 25.38 & $1,2,3$ & \\
\hline 14 & $\alpha$-Copaene & 1376 & 1487 & 0.14 & 1,2 & [34] \\
\hline 15 & Caryophyllene & 1419 & 1598 & 4.13 & $1,2,3$ & \\
\hline \multirow[t]{5}{*}{16} & $\delta$-Cadinene & 1530 & 1722 & 0.07 & 1,2 & \\
\hline & Monoterpene Hydrocarbons & & & 49.96 & & \\
\hline & Oxygenated Monoterpenes & & & 43.67 & & \\
\hline & Sesquiterpene Hydrocarbons & & & 4.34 & & \\
\hline & Total & & & 97.97 & & \\
\hline
\end{tabular}

a: retention index on a HP-5MS apolar column; ${ }^{\text {b }}$ : retention index on a DB-Wax polar column. ${ }^{\mathrm{c}}$ : $1=$ retention $^{\mathrm{N}}$ index identical to bibliography; 2 = identification based on comparison of MS; 3 = retention time identical to authentic compounds; ${ }^{\mathrm{d}}$ : tentative identification. Compounds are classified in order of linear retention time of apolar column.

Table 2. Chemical composition of C. maritimum essential oil.

\begin{tabular}{ccccccc}
\hline No. & Compounds & LRI $^{\mathbf{a}}$ & LRI $^{\mathbf{b}}$ & Area (\%) & Ident. $^{\mathbf{c}}$ & Ref. $^{\text {Are }}$ \\
\hline 1 & $\alpha$-Pinene & 932 & 1019 & 5.51 & $1,2,3$ & \\
2 & Camphene & 944 & 1060 & 5.16 & $1,2,3$ & \\
3 & Sabinene & 966 & 1114 & 0.21 & 1,2 & \\
4 & $\beta$-Pinene & 974 & 1070 & 0.55 & $1,2,3$ & \\
5 & $\beta$-Myrcene & 990 & 1079 & 13.66 & $1,2,3$ & \\
6 & $\alpha$-Phellandrene & 998 & 1166 & 0.88 & 1,2 & \\
7 & p-Cymene & 1021 & 1224 & 11.67 & $1,2,3$ & \\
8 & $\beta$-Phellandrene & 1022 & 1201 & 6.57 & 1,2 & \\
9 & $\gamma$-Terpinene & 1049 & 1233 & 0.87 & 1,2, & \\
10 & $\beta$-Linalool & 1098 & 1498 & 0.43 & $1,2,3$ & \\
11 & cis-2-Menthenol & 1118 & 1527 & 0.39 & 1,2 & {$[35]$} \\
12 & Camphor & 1122 & 1501 & 0.27 & $1,2,3$ & {$[36]$} \\
13 & 3-Methylbutyl pentanoate & 1134 & 1345 & 0.16 & 1,2 & \\
14 & trans-2-Menthenol & 1136 & 1561 & 0.56 & 1,2 & {$[37]$} \\
15 & Camphene hydrate & 1148 & 1583 & 0.09 & 1,2 & \\
16 & Terpinen-4-ol & 1177 & 1612 & 3.52 & 1,2 & \\
17 & Pentyl pentanoate & 1185 & 1402 & 0.51 & 1,2 & \\
18 & trans-3(10)-Caren-2-ol & 1194 & 1525 & 0.18 & 1,2 & {$[38]$} \\
19 & 1-Methylhexyl butanoate & 1197 & 1371 & 0.63 & 1,2 & {$[39]$} \\
20 & Carvone & 1218 & 1709 & 0.24 & $1,2,3$ & \\
21 & cis-Carveol & 1222 & 1820 & 0.19 & 1,2 & \\
22 & Thymol methyl ether & 1235 & 1587 & 1.23 & 1,2 & \\
\hline
\end{tabular}


Table 2. Cont.

\begin{tabular}{|c|c|c|c|c|c|c|}
\hline No. & Compounds & LRI $^{a}$ & LRI $^{b}$ & Area $(\%)$ & Ident. $^{c}$ & Ref. \\
\hline 23 & 2-Methylcyclohexyl butyrate ${ }^{\mathrm{d}}$ & 1241 & 1407 & 0.37 & 1,2 & \\
\hline 24 & 4,7-Dimethylbenzofuran & 1260 & 1619 & 0.54 & 1,2 & [40] \\
\hline 25 & Thymol & 1267 & 2156 & 2.62 & $1,2,3$ & \\
\hline 26 & Bornyl acetate & 1270 & 1555 & 2.69 & 1,2 & \\
\hline 27 & Piperitone & 1277 & 1730 & 0.40 & 1,2 & \\
\hline 28 & 2-Undecanone & 1295 & 1614 & 0.27 & 1,2 & \\
\hline 29 & Thymol acetate & 1352 & 1813 & 14.38 & $1,2,3$ & \\
\hline 30 & 4-Cyclohexyl-2-butanone ${ }^{\mathrm{d}}$ & 1371 & 1823 & 0.10 & 1,2 & \\
\hline 31 & Damascenone & 1385 & 1810 & 0.48 & 1,2 & \\
\hline 32 & $\alpha$-Ionol & 1395 & 1881 & 0.29 & 1,2 & \\
\hline 33 & $\begin{array}{l}\text { 1,4-Dimethoxy-2-tert- } \\
\text { butylbenzene }\end{array}$ & 1408 & 1871 & 1.23 & 1,2 & [41] \\
\hline 34 & $\alpha$-Methylbenzyl propionate ${ }^{\mathrm{d}}$ & 1412 & 1853 & 0.99 & 1,2 & \\
\hline 35 & 2-Methyl-6-(2-propenyl)phenol ${ }^{\mathrm{d}}$ & 1423 & 1889 & 3.30 & 1,2 & \\
\hline 36 & Geranyl acetone & 1456 & 1859 & 0.30 & 1,2 & \\
\hline 37 & Bornyl butyrate & 1463 & 1760 & 1.30 & 1,2 & \\
\hline 38 & $\gamma$-Cadinene & 1521 & 1776 & 1.94 & 1,2 & \\
\hline \multirow[t]{7}{*}{39} & 2,3,4-Trimethylacetophenone & 1548 & 1882 & 5.35 & 1,2 & \\
\hline & Monoterpene Hydrocarbons & & & 45.08 & & \\
\hline & Oxygenated Monoterpenes & & & 40.03 & & \\
\hline & Sesquiterpene Hydrocarbons & & & 1.94 & & \\
\hline & Oxygenated Sesquiterpenes & & & 0.50 & & \\
\hline & Others & & & 2.48 & & \\
\hline & Total & & & 90.03 & & \\
\hline
\end{tabular}

a: retention index on a HP-5MS apolar column; ${ }^{b}$ : retention index on a DB-Wax polar column. ${ }^{\mathrm{c}}: 1=$ retention index identical to bibliography; 2 = identification based on comparison of MS; 3 = retention time identical to authentic compounds; ${ }^{\mathrm{d}}$ : tentative identification. Compounds are classified in order of linear retention time of apolar column.

\subsection{Antimicrobial Activity}

In order to test the antimicrobial activity of T. vulgaris and C. maritimum EOs against bacteria species isolated from Tholu Bommalu, an agar disk diffusion method (ADD) was performed (results are listed in Table 3). As far as the T. vulgaris EO was concerned, Georgenia sp. isolated colonies were the most susceptible to the oil; in this case, the antimicrobial activity was so high that the inhibition halos were confluent. Every bacterial colony showed a relevant sensitivity to both EO solutions ( $50 \%$ and $100 \%)$, which were able to produce inhibition halos of up to $33 \mathrm{~mm}$. In contrast, the C. maritimum essential oil did not show inhibition halos, except in the case of Bacillus sp., although these inhibition halos were smaller than those of T. vulgaris.

Table 3. Antimicrobial activity of T. vulgaris EO using ADD method.

\begin{tabular}{cccccc}
\hline EO/Solvents & Conc. (\%) & \multicolumn{4}{c}{ Inhibition Halos $\mathbf{( m m})^{\mathbf{a}} \times$ Bacterial Specie } \\
\hline \multirow{2}{*}{ T. vulgaris EO } & 50 & Bacillus & Georgenia & Streptomyces & Ornithinibacillus \\
& 100 & 33 & confl. $^{\mathrm{b}}$ & 42 & 39 \\
C. maritimum EO & 50 & 9 & confl. $^{\mathrm{b}}$ & 46 & 54 \\
Benzalkonium & 100 & 10 & 0 & 0 & 0 \\
chloride & 3 & 7 & 9 & 0 & 6 \\
Pentane & 100 & 0 & 0 & 0 & 0 \\
\hline
\end{tabular}

a Inhibition halo diameter, including paper disk diameter $(6 \mathrm{~mm})$. Sensitive strains $>9 \mathrm{~mm}$; not sensitive $<9 \mathrm{~mm}$

${ }^{b}$ Confluent: microbial growth on the entire surface of agar medium.

The antimicrobial activity of the T. vulgaris EO was displayed against all isolated colonies and clearly had a greater effect than that of the controls (benzalkonium chloride 
(BAK), the reference biocide, and pentane, as shown in Figure 1). Completely in contrast was the antimicrobial activity of the C. maritimum EO, which produced inhibition halos smaller than those produced by the controls.

(a)

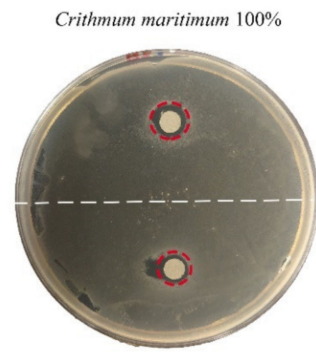

Crithmum maritimum $50 \%$

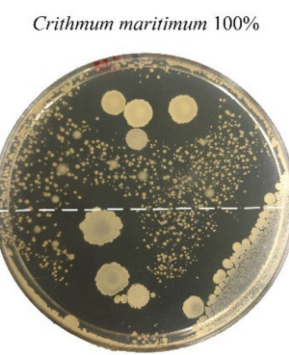

Crithmum maritimum $50 \%$

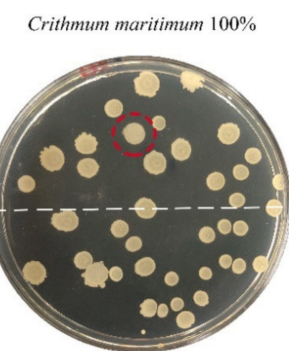

Crithmum maritimum 50\%

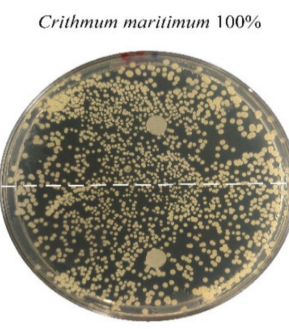

Crithmum maritimum 50\%

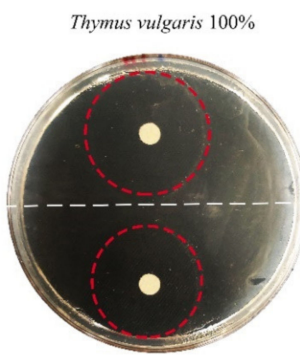

Thymus vulgaris $50 \%$

Thymus vulgaris $100 \%$

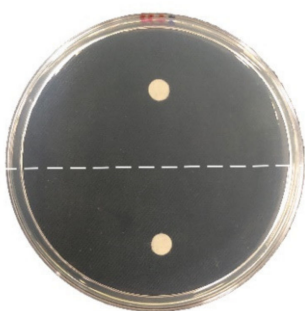

Thymus vulgaris $50 \%$

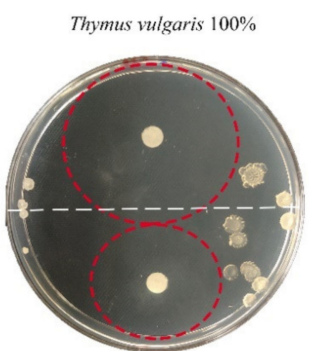

Thymus vulgaris $50 \%$

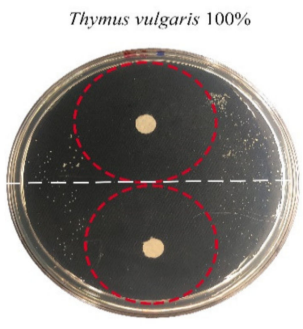

Thymus vulgaris 50\%

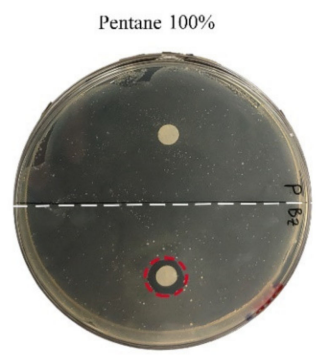

Benzalkonium chloride $3 \%$.

Pentane $100 \%$

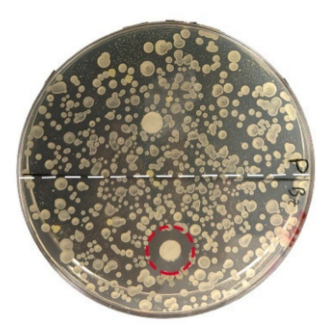

Benzalkonium chloride 3\%

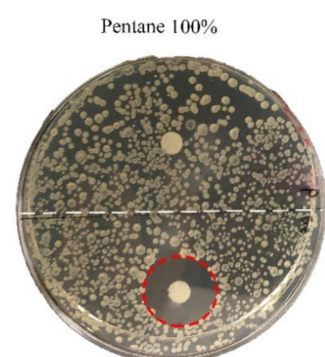

Benzalkonium chloride $3 \%$

Pentane $100 \%$

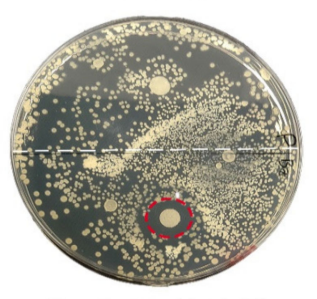

Benzalkonium chloride $3 \%$

Figure 1. Inhibition halos highlighted using ADD method with T. vulgaris and C. maritimum EOs and control BAK against (a) Bacillus sp., (b) Georgenia sp., (c) Ornithinibacillus sp. and (d) Streptomyces sp.

The biocide properties of the T. vulgaris EO are in agreement with its chemical composition. Several studies highlighted how EOs rich in phenolic compounds, such as thymol or carvacrol, have a strong antimicrobial activity. In particular, thymol seems to be bioactive against more than twelve different bacterial colonies [21,42].

\subsection{Use of a Vaccum Chamber for the Disinfection Process}

Considering the huge presence of microbial colonies on Tholu Bommalu and the fragility of the parchment support, the aim was to find a disinfection process that was minimally invasive but also fast, allowing replicability in the future for the entire collection of Indian shadow puppets stored in the International Puppets Museum, "Antonio Pasqualino". 
The study focused on observing the growth of isolated microbial colonies in response to their exposure to volatile compounds of the Thymus vulgaris EO, under both normal evaporation conditions and under vacuum inside a Plexiglas chamber (Figure 2).

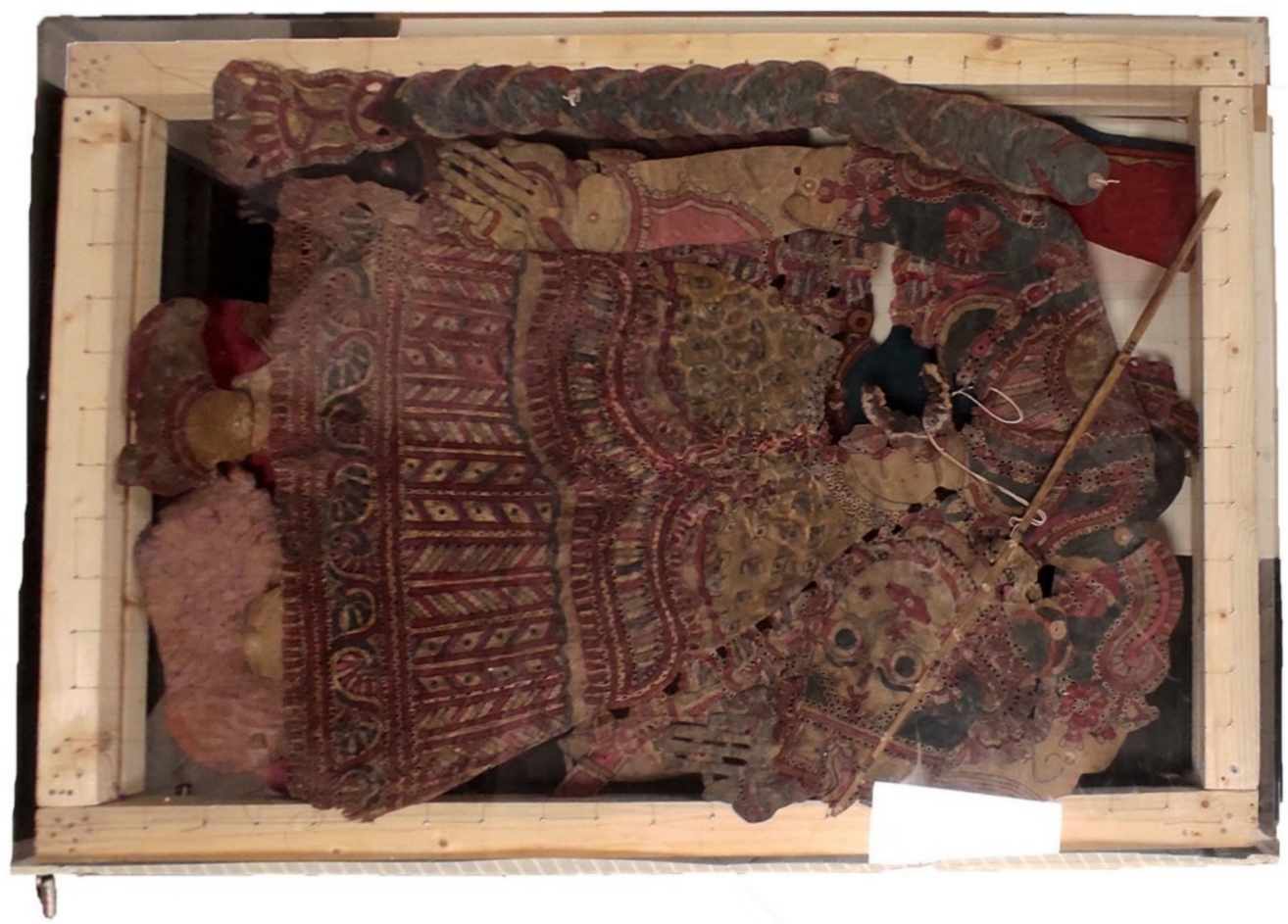

Figure 2. Tholu Bommalu exposed to volatile compounds of EO inside the Plexiglas chamber under vacuum.

In order to track the microbial growth on Tholu Bommalu fragments affected by bacterial colonies, surface sampling was performed weekly both on the samples in the clean chamber and in the vacuum chamber. The exposure of the fragments to EO volatile compounds lasted a total of five weeks. T. vulgaris essential oil manifested a marked reduction in microbial growth over time. This was observed in both the group of samples. However, a clear difference was observed between the two methods, demonstrating that the exposure under vacuum allowed for faster inhibition of microbial growth.

Microbial in vitro cultures were performed on both nutrient agar (Oxoid, Thermo Fisher: $1.0 \mathrm{~g}$ Lab-Lemco powder; $5.0 \mathrm{~g}$ peptone; $5.0 \mathrm{~g} \mathrm{NaCl} ; 15.0 \mathrm{~g}$ agar/liter of $\mathrm{dH}_{2} 0$ ) and Sabouraud dextrose agar (Oxoid, Thermo Fisher: $40.0 \mathrm{~g}$ dextrose; $10.0 \mathrm{~g}$ peptone; $15.0 \mathrm{~g}$ agar/liter of $\mathrm{dH}_{2} \mathrm{O}$ ). Nutrient agar supports a wide range of microorganisms, whereas Sabouraud is mainly used to cultivate fungi or filamentous bacteria.

The results from these different culture media were combined and evaluated, revealing the microbial growth trend over time for each fragment (as shown in Figure 3). 


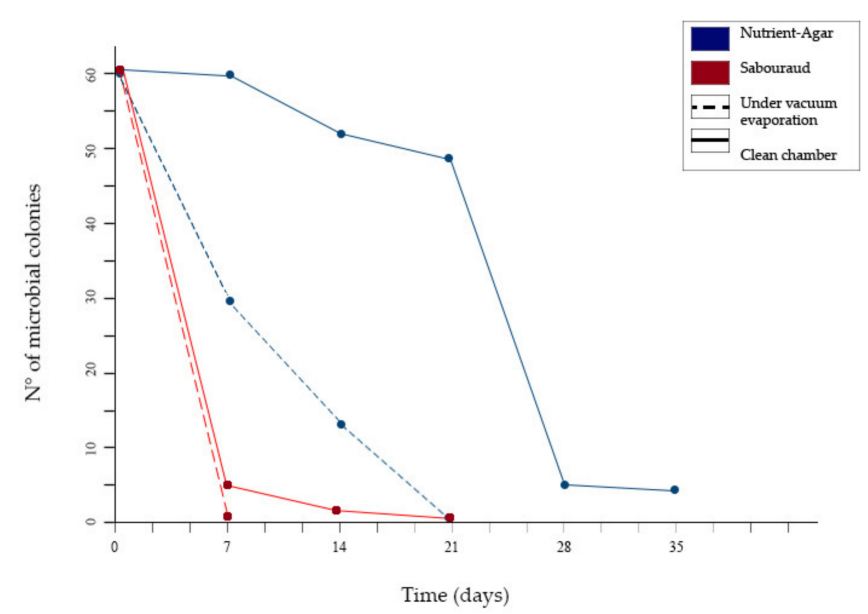

(a)

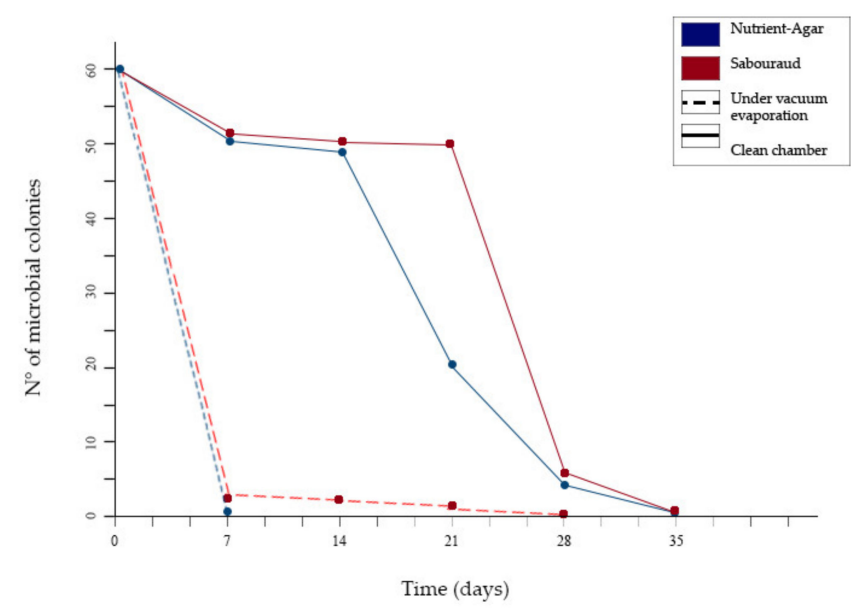

(c)

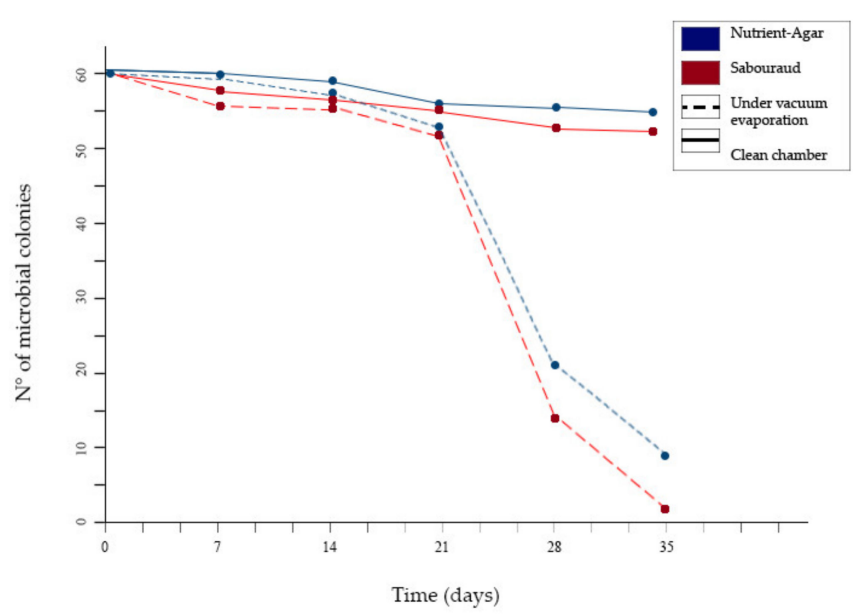

(b)

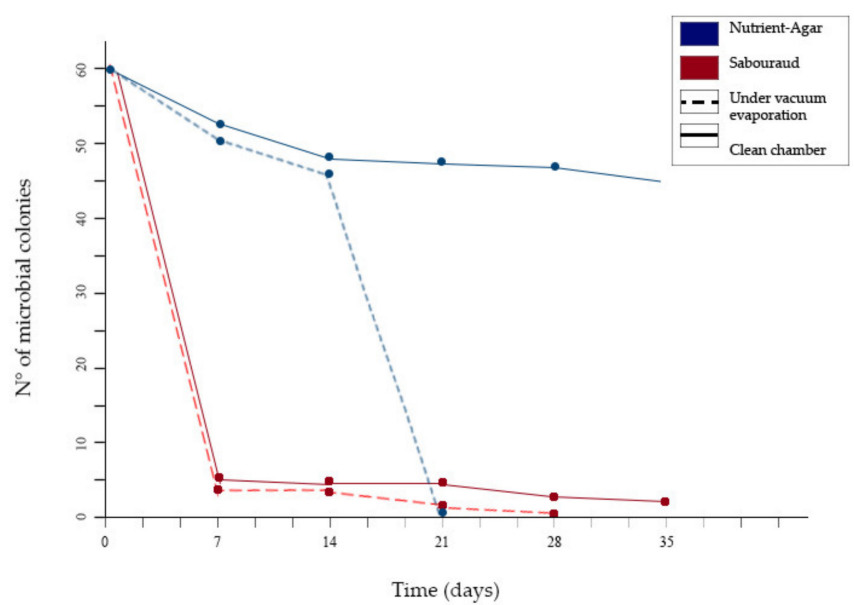

(d)

Figure 3. Microbial growth trends over time for fragments " $A$ " (a); “ $B$ " (b); “ $C$ " (c) and “ $D$ " (d).

In particular, one of the clearest results was related to the colonies sampled from fragments " $\mathrm{A}$ " and " $\mathrm{C}$ " and grown on nutrient agar, which were significantly reduced in fragment " $\mathrm{A}$ " and completely absent in fragment " $\mathrm{C}$ " from the first week of exposure to EO volatile compounds. On the contrary, the same colonies exposed in the clean chamber without the vacuum showed confluent growths.

Colonies collected on surfaces of the " $\mathrm{A}$ " and " $\mathrm{C}$ " fragments showed differences in terms of the microbial load. Specifically, after only one week of exposure to EO volatile compounds under vacuum no microbial growth was observed, whereas microbial growth was still present under ambient conditions, although considerably reduced.

By the third week, the exposure to T. vulgaris $\mathrm{EO}$ volatile compounds under vacuum conditions resulted in the microbial colonies on " $\mathrm{A}$ " and " $\mathrm{C}$ " fragments being completely eradicated. In contrast, under environmental conditions, the microbial colonies were still present, revealing a considerable reduction in the microbial load only after the fourth week of the disinfection process.

In regard to fragments " $\mathrm{B}$ " and " $\mathrm{D}$ ", the microbial colonies present on their surfaces immediately proved to be more resistant to the action of the EO, showing confluent growth in all cases. The first result of microbial growth inhibition was observed from the fourth week of exposure. Under vacuum conditions, the colonies present in " $\mathrm{B}$ " were significantly reduced on both nutrient and Sabouraud agar when compared to the same fragments exposed under environmental conditions. Regarding fragment " $\mathrm{D}$ ", the microbial growth tested on Sabouraud agar was almost completely eradicated under vacuum conditions and 
was significantly reduced under environmental conditions. Microbial growth remained confluent on nutrient agar.

Reaching the fifth week of exposure to EO volatile compounds, microbial growth had almost completely stopped under vacuum conditions. The only exception was fragment " $\mathrm{B}$ ", although in this case, the microbial load was still reduced. This result was completely in contrast with the exposure under environmental conditions, in which confluent growth was still present after 35 days of disinfection, although only for some taxa.

An important aspect, which must be emphasized, is that a non-topical and direct application on the leather fragments and on the entire artifact using only the vapor pressure of the EO did not cause decolorization processes. This aspect was checked with the aid of a colorimeter (NH300 Colorimeter, 3NH Shanghai Co., Ltd.), evaluating parameters such as total color differences $(\Delta \mathrm{E}), \mathrm{a}$ * (red-green), $\mathrm{L}$ * (lightness) and $\mathrm{b}$ * (yellow-blue) before and after the EO treatment.

Furthermore, to avoid discomfort and residual odor of the same on the artifact, the latter was subjected to three high vacuum cycles, maintaining stable thermo-hygrometric parameters, in order to eliminate the possible presence of some volatile components of the essential oil.

\section{Materials and Methods}

\subsection{Essential Oils}

The essential oil of Thymus vulgaris (100\% pure, $100 \mathrm{~mL}$ ) was purchased from Authentic Oil Co, Unit 1, Little Castle Farm, Raglan, Monmouthshire, NP15 2BX, UK. In this case, the aerial parts of T. vulgaris come from Daran, Karaman, Turkey.

The aerial parts of Crithmum maritimum were collected in Addaura (Mondello), Palermo, Sicily, Italy ( $38^{\circ} 11^{\prime} 31^{\prime \prime} \mathrm{N}, 13^{\circ} 20^{\prime} 41^{\prime \prime} \mathrm{E}, 2 \mathrm{~m}$ m.s.l.), in June 2020 and a voucher specimen was deposited in STEBICEF Department, University of Palermo (PAL 348/20).

A quantity of $300 \mathrm{~g}$ of the aerial parts of $C$. maritimum were subjected to hydrodistillation for $3 \mathrm{~h}$ using Clevenger's apparatus [43]. The oil (yield 2.08\% $(v / w)$ ) was dried with anhydrous sodium sulfate, filtered and stored in a freezer at $-20{ }^{\circ} \mathrm{C}$ until the time of analyses.

\subsection{GC-MS Analysis of Essential Oil}

Analyses of essential oils were performed according to the procedure reported by Rigano et al. [44]. EO analysis was performed using an Agilent 7000 C GC (Agilent Technologies, Inc., Santa Clara, CA, USA) system, fitted with a fused silica Agilent DBWax capillary column (30 m $\times 0.25 \mathrm{~mm}$ i.d.; $0.25 \mu \mathrm{m}$ film thickness $)$ and coupled to an Agilent triple quadrupole Mass Selective Detector MSD 5973 (Agilent Technologies, Inc., Santa Clara, CA, USA). The settings were as follows: ionization voltage, $70 \mathrm{eV}$; electron multiplier energy, $2000 \mathrm{~V}$; transfer line temperature, $295^{\circ} \mathrm{C}$; solvent delay, $4 \mathrm{~min}$. The other GC analysis was performed with a Shimadzu QP 2010 plus equipped with an AOC-20i autoinjector (Shimadzu, Kyoto, Japan), gas chromatograph equipped with a flame ionization detector (FID), a capillary column (HP-5MS) (30 $\mathrm{m} \times 0.25 \mathrm{~mm}$ i.d.; film thickness, $0.25 \mu \mathrm{m})$ and a data processor. The oven program was as follows: temperature increase at $40{ }^{\circ} \mathrm{C}$ for $5 \mathrm{~min}$ at a rate of $2{ }^{\circ} \mathrm{C} / \mathrm{min}$ up to $260^{\circ} \mathrm{C}$ and then isothermal amplification for $20 \mathrm{~min}$. Helium was used as the carrier gas $\left(1 \mathrm{~mL} \mathrm{~min}^{-1}\right)$. The injector and detector temperatures were set at $250^{\circ} \mathrm{C}$ and $290^{\circ} \mathrm{C}$, respectively. An amount of $1 \mu \mathrm{L}$ of each oil solution $(3 \% \mathrm{EO} /$ hexane $v / v)$ was injected with a split mode. Linear retention indices (LRI) were determined by using retention times of $n$-alkanes $\left(\mathrm{C}_{8}-\mathrm{C}_{40}\right)$, and the peaks were identified by comparison with mass spectra and by comparison to their relative retention indices with WILEY275 (Wiley), NIST 17 (NIST, The National Institute of Standards and Technology, Gaithersburg, MD, USA), ADAMS (Allured Business Media, Carol Stream, IL, USA) and FFNSC2 (Shimadzu, Kyoto, Japan) libraries. 


\subsection{ADD Control Solutions}

Benzalkonium chloride ( $3 \% v / v)$ (Sigma Aldrich, St. Louis, MO 68178 United States), the reference biocide, and pentane (Sigma Aldrich, 100\%, St. Louis, MO 68178, USA), the solvent accounting for fifty percentage of the EO solution, were controls used in agar disc diffusion (ADD) assays [45,46]. ADD assays, performed on nutrient or Sabouraud agar media, were performed twice.

\subsection{Microbial Taxa}

Microbial patina on the leather substrata of Tholu Bommalu was sampled by sterile stubs. Distinctive colonies, in morphology and/or pigmentation, were isolated on the nutrient agar in vitro culture. Taxonomical identification was performed by molecular analysis of the 16S rDNA gene or ITS1-2 containing DNA region [47]. Specifically, Bacillus sp., Georgenia sp., Ornithinibacillus sp. and Streptomyces sp. were identified as the prevalent genera (Gram + bacteria).

\subsection{Antibacterial Activity Assays}

The ADD in vitro method was performed to evaluate the antibacterial activity of EO and BAK solutions. An amount of $10 \mu \mathrm{L}$ of each bacterial broth culture (normalized to the concentration of $1 \times 106 \mathrm{CFU} / \mathrm{mL}$ ) was uniformly spread using a sterile Drigalsky spatula on the nutrient agar surface, and the surface was allowed to dry $\left(1 \mathrm{~h}\right.$ at $\left.30^{\circ} \mathrm{C}\right)$. A sterile paper disc (6 mm in diameter, Dutscher papier, FR) imbibed with $10 \mu \mathrm{L}$ of the T. vulgaris essential oil ( $100 \%$ or $50 \%$ ) or control solutions (BAK $3 \% v / v$ and pentane $100 \%$,) was leaned on the agar medium ( $9 \mathrm{~cm}$ Petri dishes) surface. Due to the non-miscibility of essential oils in water, fifty percent of the EO solution was composed of pentane. After incubation at $30{ }^{\circ} \mathrm{C}$ for $24 \mathrm{~h}$, inhibition halos (i.hs.) differing in diameter $(\mathrm{mm})$ were revealed, reflecting the antimicrobial activity and categorized as a sensitive strain (i.h. $>9 \mathrm{~mm}$ ) or a resistant strain (i.h. $<9 \mathrm{~mm}$ ). Georgenia sp. colonies were the most susceptible isolated bacteria, showing a relevant sensitivity to the essential oil with an inhibition zone of up to $18 \mathrm{~mm}$. At the other end of the spectrum, Bacillus sp. was the most resistant with an i.h. of 14-17 mm diameters. Table 2 shows the results of the antibacterial activity using the ADD method (Figure 1). Pentane, accounting for fifty percent of the EO solution, was applied as a control to evaluate the real biocide power of the diluted EO, and it did not show inhibition halos.

\subsection{Vacuum Chamber}

In order to maintain stable thermo-hygrometric parameters $\left(13-18{ }^{\circ} \mathrm{C} ; 50-60 \% \mathrm{RH}\right)$, a saturated solution of $\mathrm{MgCl}_{2}$ was placed inside the vacuum system. In addition, the chamber was filled with the Thymus vulgaris EO, calculating the right amount to saturate atmosphere using the equation of a perfect gas; a thermo-hygrometer; and the leather samples, placed on a reticulated support made of cardboard and nylon to allow the volatile compounds to easily reach all points of the samples. To create vacuum, a diaphragm vacuum pump (Type MZ 2C, Ser.No. 20635805) was connected by a tube to the top of the chamber and was kept running for about one minute and then disconnected.

\section{Conclusions}

The present work focused on determining the yield, the chemical composition and antimicrobial properties of Thymus vulgaris and Crithmum maritimum essential oils. The essential oil of T. vulgaris was characterized by a large presence of monoterpenes, $p$-cymene (35.96\%), terpinen-4-ol (10.29\%), $\alpha$-terpinene (8.85\%) and thymol $(25.38 \%)$, while C. maritimum essential oil was dominated by $\beta$-myrcene (13.66\%), followed by $p$-cymene $(11.67 \%)$, $\beta$-phellandrene $(6.57 \%)$ and thymol acetate $(14.38 \%)$. In addition, we suggested an integrated approach to the most common disinfection processes, by using a vacuum chamber in order to allow the mechanism to act faster than usual. Thymus oil, in vapor phase, is a strong inhibitor for bacterial growth; every bacterial colony isolated showed significant sensitivity to both EO solutions $(50 \%, 100 \%)$ and was able to produce inhibition halos up to 
$33 \mathrm{~mm}$. All colonies under vacuum conditions were significantly reduced compared to the same ones exposed to environmental conditions. In contrast, the $C$. maritimum essential oil did not show inhibition halos. The potential use of commercial plant essential oils, together with the achievements reached during the in vitro and in situ applications to control the growth of bacterial taxa, led us to hypothesize their use as natural biocides, replacing the most common toxic biocide usually used in the conservation of cultural heritage.

Author Contributions: Conceptualization, M.B. Methodology, G.D., N.B,. and B.G. Validation, M.B. Formal analysis, G.D. and N.B. Investigation, F.P., N.B., and M.B. Resources, M.B. Writing-original draft preparation, G.D., N.B., F.P. and M.B. Writing—review and editing, M.B. All authors have read and agreed to the published version of the manuscript.

Funding: This research received no external funding.

Acknowledgments: The authors thank Giuseppe Gallo and Teresa Faddetta for the collaboration in microbial analysis and the Museo Internazionale delle Marionette, "A. Pasqualino" Palermo, Italy, for providing the artifact and active assistance. The results regarding the application of essential oils in contrast to microbial colonization of Indian leather puppets are part of G. D'Agostino's final examination in his master's degree in Conservation and Restoration of Cultural Heritage. He graduated cum laude and qualified as an Italian Restorer of Cultural Heritage (Italian Ministry of Culture) at the University of Palermo, Italy.

Conflicts of Interest: The authors declare no conflict of interest.

\section{References}

1. Casiglia, S.; Bruno, M.; Senatore, F. Volatile constituents of Dianthus rupicola Biv. from Sicily: Activity against microorganisms affecting cellulosic objects. Nat. Prod. Res. 2014, 28, 1739-1746. [CrossRef]

2. Casiglia, S.; Bruno, M.; Senatore, F. Activity against microorganisms affecting cellulosic objects of the volatile constituents of Leonotis nepetaefolia from Nicaragua. Nat. Prod. Commun. 2014, 9, 1637-1639. [CrossRef]

3. Casiglia, S.; Ben Jemia, M.; Riccobono, L.; Bruno, M.; Scandolera, E.; Senatore, F. Chemical composition of the essential oil of Moluccella spinosa L. (Lamiaceae) collected wild in Sicily and its activity on microorganisms affecting historical textiles. Nat. Prod. Res. 2015, 29, 1201-1206. [CrossRef] [PubMed]

4. Casiglia, S.; Bruno, M.; Senatore, F.; Senatore, F. Composition of the essential oil of Allium neapolitanum Cirillo growing wild in Sicily and its activity on microorganisms affecting historical art crafts. J. Oleo Sci. 2015, 64, 1315-1320. [CrossRef] [PubMed]

5. Casiglia, S.; Riccobono, L.; Bruno, M.; Senatore, F.; Senatore, F. Chemical composition of the essential oil from Pulicaria vulgaris var. graeca (Sch.-Bip.) Fiori (Asteraceae) grown wild in Sicily and its antimicrobial activity. Nat. Prod. Res. 2016, 30, $259-267$. [CrossRef] [PubMed]

6. Casiglia, S.; Bruno, M.; Senatore, F.; Senatore, F. Chemical composition of the essential oil of Bupleurum fontanesii Guss. ex Caruel (Apiaceae) growing wild in Sicily and its activity on microorganisms affecting historical art crafts. Nat. Prod. Commun. 2016, 11, 105-108.

7. Casiglia, S.; Riccobono, L.; Bruno, M.; Rosselli, S.; Senatore, F.; Senatore, F. Chemical composition of the essential oil from Thapsia garganica L. (Apiaceae) grown wild in Sicily and its antimicrobial activity. Nat. Prod. Res. 2016, 30, 1042-1052. [CrossRef] [PubMed]

8. Casiglia, S.; Bruno, M.; Fontana, G.; Senatore, F. Chemical composition of the essential oil of Mentha pulegium L. (Linné) growing wild in Sicily and its activity on microorganisms affecting historical art crafts. Nat. Prod. Commun. 2017, 12, 311-315.

9. Casiglia, S.; Bruno, M.; Bramucci, M.; Quassinti, L.; Lupidi, G.; Fiorini, D.; Maggi, F. Kundmannia sicula (L.) DC growing in Sicily (Italy) as a rich source of germacrene D. J. Essent. Oil Res. 2017, 29, 437-442. [CrossRef]

10. Casiglia, S.; Bruno, M.; Senatore, F.; Rosselli, S. Chemical composition of essential oils of Anthemis secundiramea Biv. subsp. secundiramea (Asteraceae) collected wild in Sicily and their activity on microorganisms affecting historical art craft. Nat. Prod. Res. 2019, 33, 970-979. [CrossRef]

11. Bruno, M.; Modica, A.; Catinella, G.; Canlı, C.; Arasoglu, T.; Çelik, S. Chemical composition of the essential oil of Centaurea tomentella Hand.-Mazz. and C. haussknechtii Boiss. (Asteraceae) collected wild in Turkey and its activity on microorganisms affecting historical art craft. Nat. Prod. Res. 2019, 33, 1092-1100. [CrossRef] [PubMed]

12. Cappitelli, F.; Cattò, C.; Villa, F. The control of cultural heritage microbial deterioration. Microorganisms 2020, 8, 154. [CrossRef]

13. Sequeira, S.; Cabrita, E.J.; Macedo, M.F. Antifungals on paper conservation: An overview. Int. Biodeterior. Biodegrad. 2012, 74, 67-86. [CrossRef]

14. Matusiak, K.; Machnowski, W.; Wrzosek, H.; Polak, J.; Rajkowska, K.; Smigielski, K.; Kunicka-Styczynska, A. Application of Cinnamomum zeylanicum essential oil in vapour phase for heritage textiles disinfection. Int. Biodeterior. Biodegrad. 2018, 131, 88-96. [CrossRef] 
15. Cimanga, K.; Kambu, K.; Tona, L.; Apers, S.; De Bruyne, T.; Hermans, N.; Tottè, J.; Pieters, L.; Vlietinck, A.J. Correlation between chemical composition and antibacterial activity of essential oils of some aromatic medicinal plants growing in the Democratic Republic of Congo. J. Ethnopharmacol. 2002, 79, 213-220.

16. Scaffaro, R.; Maio, A.; D’Arrigo, M.; Lo Presti, F.; Marino, A.; Bruno, M.; Nostro, A. Morpho-mechanical and antimicrobial properties of Coridothymus capitatus L. essential oil loaded into ultrafine poly (lactic acid) fibers prepared by electrospinning Future Microbiol. 2020, 15, 1379-1392. [CrossRef] [PubMed]

17. De Feo, V.; Bruno, M.; Tahiri, B.; Napolitano, F.; Senatore, F. Chemical composition and antibacterial activity of the essential oils of Thymus spinulosus Ten. (Lamiaceae). J. Agric. Food Chem. 2003, 51, 3849-3853. [CrossRef]

18. De Martino, L.; Bruno, M.; Formisano, C.; De Feo, V.; Napolitano, F.; Rosselli, S.; Senatore, F. Chemical composition and antimicrobial activity of the essential oils from two species of Thymus growing wild in Southern Italy. Molecules 2009, 14, 4614-4624. [CrossRef]

19. Casiglia, S.; Bruno, M.; Scandolera, E.; Senatore, F. Influence of harvesting time on composition of the essential oil of Thymus capitatus (L.) Hoffmanns. \& Link. growing wild in northern Sicily and its activity on microorganisms affecting historical art crafts. Arab. J. Chem. 2019, 12, 2704-2712.

20. Palla, F.; Bruno, M.; Mercurio, F.; Tantillo, A.; Rotolo, V. Essential oil as natural biocides in conservation of cultural heritage. Molecules 2020, 25, 730. [CrossRef]

21. Gagliano Candela, R.; Maggi, F.; Lazzara, G.; Rosselli, S.; Bruno, M. The essential oil of Thymbra capitata and its application as a biocide on stone and derived surfaces. Plants 2019, 8, 300. [CrossRef]

22. Al-Asmari, A.K.; Al-Faraidy, A.A.; Almuhaiza, M.S. Chemical composition of essential oil of Thymus vulgaris collected from Saudi Arabian market. Asian Pac. J. Trop. Biomed. 2017, 7, 147-150. [CrossRef]

23. De Carvalho, R.J.; Targino de Souza, G.; Gonçalves Honório, V.; Pereira de Sousa, J.; Conceição, M.L.; Maganani, M.; Leite de Souza, E. Comparative inhibitory effects of Thymus vulgaris L. essential oil against Staphylococcus aureus, Listeria monoctogenes and mesophilic starter co-culture in cheese-mimicking models. Food Microbiol. 2015, 52, 59-65. [CrossRef]

24. Pavela, R.; Maggi, F.; Cianfaglione, K.; Bruno, M.; Benelli, G. Larvicidal activity of essential oils of five Apiaceae taxa and some of their main constituents against Culex quinquefasciatus. Chem. Biodivers. 2017, 14. [CrossRef]

25. Alves-Silva, J.; Guerra, I.; Gonçalves, M.J.; Cavaleiro, C.; Cruz, M.T.; Figueirinha, A. Chemical composition of Crithmum maritimum L. essential oil and hydrodistillation residual water by GC-MS and HPLC-DAD-MS/MS, and their biological activities. Ind. Crops Prod. 2020, 149, 1-9. [CrossRef]

26. Meot-Duros, L.; Magné, C. Antioxidant activity and phenol content of Crithmum maritimum L. leaves. Plant Physiol. Biochem. 2009, 47, 37-41. [CrossRef] [PubMed]

27. Gagliano Candela, R.; Ilardi, V.; Badalamenti, N.; Bruno, M.; Rosselli, S.; Maggi, F. Essential oil compositions of Teucrium fruticans, T. scordium subsp. scordioides and T. siculum growing in Sicily and Malta. Nat. Prod. Res. 2020, in press. [CrossRef] [PubMed]

28. Ilardi, V.; Badalamenti, N.; Bruno, M. Chemical composition of the essential oil from different vegetative parts of Foeniculum vulgare subsp. piperitum (Ucria) Coutinho (Umbelliferae) growing wild in Sicily. Nat. Prod. Res. 2020, in press.

29. Badalamenti, N.; Ilardi, V.; Rosselli, S.; Bruno, M.; Maggi, F.; Leporini, M.; Falco, T.; Loizzo, M.R.; Tundis, R. Ferulago nodosa subsp. geniculata (Guss.) Troia \& Raimondo from Sicily (Italy): Isolation of essential oil and evaluation of its bioactivity. Molecules 2020, 25,3249 .

30. Badalamenti, N.; Bruno, M.; Gagliano Candela, R.; Maggi, F. Chemical composition of the essential oil of Elaeoselinum asclepium (L.) Bertol subsp. meoides (Desf.) Fiori (Umbelliferae) collected wild in Central Sicily and its antimicrobial activity. Nat. Prod. Res. 2020, in press. [CrossRef] [PubMed]

31. Di Napoli, M.; Maresca, V.; Varcamonti, M.; Bruno, M.; Badalamenti, N.; Basile, A.; Zanfardino, A. (+)-(E)-Chrysanthenyl acetate: A molecule with interesting biological properties contained in the Anthemis secundiramea (Asteraceae) flowers. Appl. Sci. 2020, 10, 6808. [CrossRef]

32. Badalamenti, N.; Ilardi, V.; Bruno, M.; Pavela, R.; Boukouvala, M.C.; Kavallieratos, N.G.; Maggi, F.; Canale, A.; Benelli, G. Chemical composition and broad-spectrum insecticidal activity of the flower essential oil from an ancient Sicilian food plant, Ridolfia segetum. Agriculture 2021, 11, 304. [CrossRef]

33. Satyal, P.; Murray, B.; McFeeters, R.; Setzer, W. Essential oil characterization of Thymus vulgaris from various geographical locations. Foods 2016, 5, 70. [CrossRef]

34. Salido, S.; Altarejos, J.; Nogueras, M.; Sánchez, A.; Pannecouque, C.; Witvrouw, M.; De Clercq, E. Chemical studies of essential oils of Juniperus oxycedrus ssp. badia. J. Ethnopharmacol. 2002, 81, 129-134. [PubMed]

35. Basta, A.; Tzakou, O.; Couladis, M. Composition of the leaves essential oil of Melissa officinalis s. 1. from Greece. Flavour Fragr. J. 2005, 20, 642-644. [CrossRef]

36. Shang, C.; Hu, Y.; Deng, C.; Hu, K. Rapid determination of volatile constituents of Michelia alba flowers by gas chromatographyMass spectrometry with solid-phase microextraction. J. Chromatogr. A 2001, 942, 283-288. [CrossRef]

37. Schmidt, J.M.; Noletto, J.A.; Vogler, B.; Setzer, W.N. Abaco Bush Medicine: Chemical composition of the essential oils of four aromatic medicinal plants from Abaco Island, Bahamas. J. Herbs Spices Med. Plants 2006, 12, 43-65. [CrossRef]

38. Iranshahi, M.; Amin, G.; Sourmaghi, M.S.; Shafiee, A.; Hadjiakhoondi, A. Sulphur-containing compounds in the essential oil of the root of Ferula persica Willd. var. persica. Flavour Fragr. J. 2006, 21, 260-261. [CrossRef] 
39. Shiota, H. New esteric components in the volatiles of banana fruit (Musa sapientum L.). J. Agric. Food Chem. 1993, 41, 2056-2062. [CrossRef]

40. Varlet, V.; Knockaert, C.; Prost, C.; Serot, T. Comparison of odor-active volatile compounds of fresh and smoked salmon. J. Agric. Food Chem. 2006, 54, 3391-3401. [CrossRef]

41. Huang, B.; Qin, L.; Chu, Q.; Zhang, Q.; Gao, L.; Zheng, H. Comparison of headspace SPME with hydrodistillation and SFE for analysis of the volatile components of the roots of Valeriana officinalis var. latifolia. Chromatographia 2009, 69, 489-496. [CrossRef]

42. Naigre, R.; Kalck, P.; Roques, C.; Roux, I.; Michel, G. Comparison of antimicrobial properties of monoterpenes and their carbonylated products. Planta Med. 1996, 62, 275-277. [CrossRef]

43. EDQM (Council of Europe). European Pharmacopoeia, 6th ed.; EDQM: Strasbourg, France, 2008.

44. Rigano, D.; Formisano, C.; Rosselli, S.; Badalamenti, N.; Bruno, M. GC and GC-MS Analysis of volatile compounds from Ballota nigra subsp. uncinata collected in Aeolian Islands, Sicily (Southern Italy). Nat. Prod. Commun. 2020, 15, 1-7. [CrossRef]

45. Balouiri, M.; Sadiki, M.; Ibnsouda, S.K. Methods for in vitro evaluating antimicrobial activity: A review. J. Pharm. Anal. 2016, 6, 71-79. [CrossRef]

46. Palla, F.; Caruana, E.; Di Carlo, E.; Rotolo, V. Plant essential oils in controlling fungal colonization on wooden substrate. Borziana 2021, 2, 5-14.

47. Johnson, J.S.; Spakowicz, D.J.; Hong, B.-Y.; Petersen, L.M.; Demkowicz, P.; Chen, L.; Leopold, S.R.; Hanson, B.M.; Agresta, H.O.; Gerstein, M.; et al. Evaluation of 16S rRNA gene sequencing for species and strain-level microbiome analysis. Nat. Commun. 2019, 10, 5029. [CrossRef] 